\title{
Applied Mineralogy for Complex and Profound Mineral Processing
}

\author{
V. Chanturiya ${ }^{(凶)}$ and T. Matveeva \\ Institute of Comprehensive Exploitation of Mineral Resources, \\ Russian Academy of Sciences, Moscow, Russia \\ vchan@mail.ru
}

\begin{abstract}
The main methodological parameters and the modes of investigation of samples containing micro- and nano-sized reagent phases are determined. Using scanning laser microscopy and an original method for analyzing the surface relief, a quantitative assessment of the adsorption layer of the collector reagent on Au-sulfide minerals was performed, the proportion of the molecular form of adsorption and the retention agent fixing strength was calculated. The theoretical basis for choosing the reagent mode for selective flotation of multicomponent ores was developed. The action mechanism has been revealed and the prospect of using novel selective collectors and environmentally friendly plant reagents for extracting non-ferrous and noble metals from complex sulfide ores has been substantiated.
\end{abstract}

Keywords: Reagent $\cdot$ Adsorption $\cdot$ Nanoparticles $\cdot$ Mineral $\cdot$ Microscopy $\cdot$ Flotation

\section{Introduction}

At present, modern mining and ore dressing plants have been facing a number of serious challenges in processing low-grade complex ores and technogenic resources, increasing demands of high quality metal concentrates and ecologically safe methods of beneficiation. In those conditions, the tasks of making mineral processing more complete and comprehensive and of creating highly effective technologies come to the fore. These should be based on the intensification of the existing methods and on creating new methods of mineral extraction from hard-to-enrich ores and from technogenic deposits by using the newest achievements of the fundamental sciences. The transition to the new strategy of primary processing is only possible on technological-mineralogical evaluation of raw minerals.

A modern complex of high-resolution physical methods allows to investigate the composition, structure and properties of geomaterials at the micro and nano-level, including:

- Identify micro and nano-sized particles of noble metals and surface natural and artificial nano-formations on minerals;

- Experimentally substantiate the structural, phase and chemical transformations of minerals under various energy methods of influence; 
- To substantiate the choice and mechanism of interaction of reagents with noble metals during flotation of complex ores of complex material composition;

- Investigate the structural, phase and chemical transformations of sulfides and rocks in heap leaching processes.

\section{Methods and Approaches}

Research methods are optical, confocal laser, analytical electronic, scanning probe microscopy, UV-spectrophotometry of reagent solutions, flotation of minerals. The KEYENCE scanning laser microscope with the surface analysis module VK-9700 enables making a non-contact measurement of the roughness of the surface of minerals and thus determining the height and size of the new formations obtained as a result of interaction with the reagents. The electronic microscope with energy-dispersive microanalyzer LEO-1420 VP INCA-350 allows determining the elemental composition of micro- and nanophases of reagents on the surface of minerals. The analysis of the surface of minerals before and after a contact with reagent solutions was carried out on polished sections made in the form of polished plates $10 \times 10 \times 2 \mathrm{~mm}$ in size.

\section{Results and Discussion}

In IPKON RAS within the framework of the scientific school of academician V. A. Chanturiya a complex of theoretical and experimental studies on the research and testing of new classes of complex-forming reagents - collectors and modifiers for flotation extraction of non-ferrous and noble metals from refractory gold-bearing oreshave been made. To analyze the processes of physicochemical effects of flotation reagents on micro and nano inclusions of gold and platinum on the surface of sulfides, the authors first developed and improved methods for obtaining samples of mineral complexes that mimic natural sulfides containing "invisible" or submicron gold or platinum. The new highly effective reagents developed in IPKON RAS are modified diethyldithiocarbamate DEDTC and diisobutyldithiophosphinate DIFM, dithiazine derivatives MTX and dialkylpyrylmethane DAM. Those reagents showed the effect for extracting micro- and nanoparticles of noble metals while enriching the mineral raw materials of complex composition owing to formation of poorly water soluble gold compounds and their selective adsorption on gold containing sulfides, improving the flotation selectivity compared to traditional xanthate collector (Chanturiya 2017; Chanturiya et al. 2016; Matveeva et al. 2017a; Matveeva et al. 2017b). Studies were carried out using a set of UV and IR spectroscopy methods (UV-1700 Shimadzu and Infralum FT-8), analytical scanning electron (ASEM) (LEO 1420VP with INCA Oxford micro 350) and laser (KEYENCE VK-9700) microscopy, X-ray phase analysis (X-ray diffractometry). The results made it possible to establish the conditions for the formation of an adsorption layer of new reagents on micro- and nanoparticles of noble metals and to ensure an increase in gold recovery during flotation (Fig. 1). 

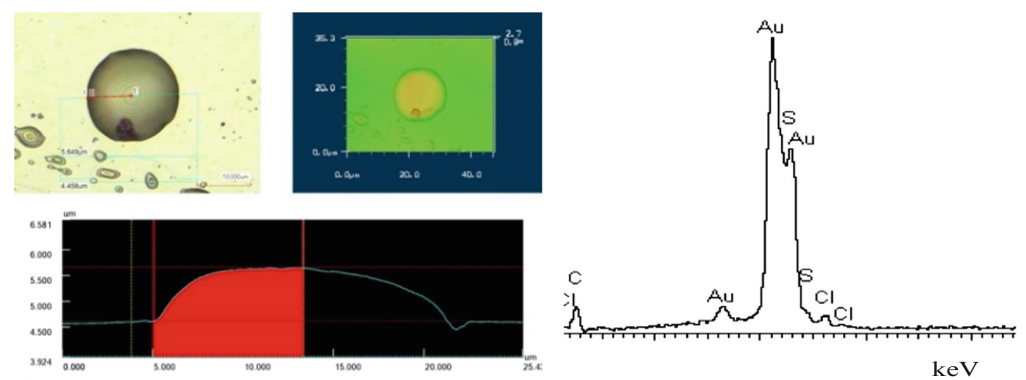

Fig. 1. Adsorbed layer of collector DEDTCm on the surface of Au-pyrite.

As the major losses, from $25 \%$ to $30 \%$ of valuable components (gold and minerals of the platinum group), are accounted for by the micro- and nano-size of the mineral particles whose concentration in the ore does not generally exceed 1,5-3,0 g/t, it was necessary to obtain samples imitating natural minerals. IPKON RAS has scientifically substantiated and offered procedures for artificially coating minerals with $\mathrm{Au}$ and $\mathrm{Pt}$ micro- and nano-particles, which made it possible to investigate the interaction mechanism for a new class of frothing agents with noble metals.

The introduction of the new agents both increased the extraction and improved the quality of the mineral concentrate in the mineral processing of rebellious ores of noble metals with a complex material composition, Table 1.

Table 1. Indicators of flotation of the low-grade sulfide ore of the Fyodorovo-Panskoye deposit when employing DEDTCm and ButX

\begin{tabular}{l|c|l|l|l}
\hline Flotation products & $\beta P d$ & $\beta P t$ & $\varepsilon P d$ & $\varepsilon P t$ \\
\hline ButX Conc. & 3.88 & 1.02 & 73.97 & 72.33 \\
\hline Tails & 0.21 & 0.06 & 26.03 & 27.67 \\
\hline Ore & 0.7 & 0.19 & 100 & 100 \\
\hline DEDTCmConc. & 10.14 & 4.24 & 82.23 & 85.31 \\
\hline Tails & 10.18 & 0.06 & 17.77 & 14.69 \\
\hline Ore & 0.93 & 0.38 & 100 & 100 \\
\hline
\end{tabular}

The implementation of new technologies at the mining-enrichment works in Russia will make it possible to increase metal extraction by $10-15 \%$, to obtain high-grade finished products that are competitive in the world market, to involve unpayable ores and technogenic raw materials into processing and considerably ameliorate negative effects on the environment in the mining industry regions. 


\section{Conclusions}

The development of the mining sciences should be based on modern achievements of applied mineralogy and innovative development of comprehensive, economic and effective exploitation of mineral resources. The novel methods ensure both the higher level of mineral extraction, the higher grade of obtained valuable components and high level of ecological safety.

Acknowledgements. The authors are grateful to the Grant of the President of RF "Scientific School" of acad. V.A. Chanturiya and Program of Presidium of RAS P39.

\section{References}

Chanturiya VA (2017) Scientific substantiation and development innovative complex processing of mineral resources. Gornyi J 11:7-13

Chanturiya VA, Matveeva TN, Ivanova TA, Getman VV (2016) Mechanism of interaction of cloud point polymers with platinum and gold in flotation of finely disseminated precious metal ores. Miner Process Extr Metall Rev 37(3):187-195

Matveeva TN, Gromova NK, Minaev VA, Lantsiova LB (2017a) Modification of sulfide minerals surface and cassiterite by stable complexes Me-dibutylditiocarbamate. Obogashchenierud 5:15-20. https://doi.org/10.17580/or.2017.05.03

Matveeva TN, Ivanova TA, Getman VV, Gromova NK (2017b) New flotation reagents for extraction of micro- and nano-particles of noble metals from refractory ores. Gornyi J 11:89-93

Open Access This chapter is licensed under the terms of the Creative Commons Attribution 4.0 International License (http://creativecommons.org/licenses/by/4.0/), which permits use, sharing, adaptation, distribution and reproduction in any medium or format, as long as you give appropriate credit to the original author(s) and the source, provide a link to the Creative Commons license and indicate if changes were made.

The images or other third party material in this chapter are included in the chapter's Creative Commons license, unless indicated otherwise in a credit line to the material. If material is not included in the chapter's Creative Commons license and your intended use is not permitted by statutory regulation or exceeds the permitted use, you will need to obtain permission directly from the copyright holder.

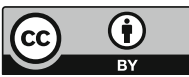

